研究

\title{
放電プラズマ焼結法によるシリコン研削スラッジの高純度化
}

\author{
坂本 直道的1, 安野 拓也的 1 , 玄場 公規的 2 , 松宮 裕介的 3 , 林正裕的 3 \\ 的いわき明星大学科学技術学部, ₹970-8551 いわき市中央台飯野 5-5-1. \\ 部立命館大学 MOT 大学院テクノロジー・マネジメント研究科, テ 525-8577 草津市野路東 1-1-1. \\ 斗侏林商会，干580-0006 松原市大堀 1-15-29.
}

\section{Purification of Silicon Grinding Sludge by Spark Plasma Sintering}

\author{
Naomichi Sakamoto ${ }^{\text {th } 1}$, Takuya Yasuno ${ }^{\text {मे } 1}$, Kiminori Gemba ${ }^{\text {出 } 2}$,

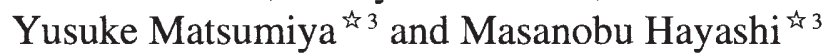 \\ ${ }^{4}$ College of Science and Engineering, Iwaki Meisei University, Iwaki 970-8551, Japan. \\ ${ }^{2}$ Graduate School of Technology Management, Ritsumeikan University, Kusatsu 525-8577, Japan. \\ ${ }^{2}$ Hayashi Co., Ltd., Matsubara 580-0006, Japan
}

Received January 5, 2010

\section{SYNOPSIS}

Recycling possibilities of silicon grinding sludge using spark plasma sintering (SPS) method were investigated. The silicon grinding sludge taken out from wastewater in silicon wafer production process was sintered by the SPS method. Sintering experiment results showed that production of sintered compacts was possible from the silicon sludge by SPS. Density and hardness of sintered compacts were increased with both sintering temperature and holding time. Results of composition analyses indicated that the sintering increased silicon purity of the compacts due to decreasing oxygen content. The content of silicon in the sintered compact was increased up to about 20 mass\% compared with that in the silicon sludge. XRD analysis suggested also decreasing oxygen content by the sintering. Therefore, it was revealed that higher-purity silicon sintered compacts were produced by sintering of the silicon sludge with the SPS method in our study.

KEY WORDS

spark plasma sintering, silicon grinding sludge, purification, silicon purity, oxygen content

\section{1 緒言}

シリコンチップは, シリコンインゴットをスライシング・ ラッピング・ポリッシングなどの処理を施して得られるシリ コンウェハ上に，イオン注入・成膜・リソグラフ・エッチン グ・パッケージングなど様々な行程を経て製造されている. この製造工程において，シリコンの収率は約 $30 \%$ と少なく, 残りの $70 \%$ は廃棄物として取り扱われている ${ }^{1)}$. 廃棄物とな るシリコンの切削・研削・研磨屑は, 多量の水分を含むスラッ ジとして排出される. 排出されたスラッジは凝集剂を添加, 滤過することによって回収されるため, 凝集剤に起因する不 純物や自然酸化被膜を多く含む ${ }^{2)}$. したがって，スラッジの シリコン純度は著しく低い. 高い純度のスラッジが得られれ ば様々な分野にわたって再利用が可能であるが, 純度が低い ために実際には埋め立て処理もしくは焼却した後に埋め立て 処理されている.しかしながら，スラッジ中には除去加工に 用いた切削油や研削油が含まれるため, 埋め立て処理に際し
てオイルやグリコールなどによる環境污染が懸念される3). また, 半導体産業全体で廃棄されているシリコンスラッジの 総量は膨大で, 埋め立て問題のみならず焼却による炭酸ガス の発生などの環境負荷が近年大きな問題となってきており4), 安全な再利用法の確立が望まれる.

シリコンスラッジの発生量のうち, 約 $2 / 3$ はシリコンイン ゴットの切断・研磨・スライス・面取り工程において発生す ると言われている5 . この工程で排出されるスラッジはイオ ン注入・成膜工程より前であるため比較的シリコンの純度が 高くリサイクルに適していると考えられる. しかし, このス ラッジを従来技術で高純度化することは理論的に可能である が, 莫大なコストがかかるため工業的な実施までには至って いない. また, スラッジから取り扱いの容易なシリコンのバ ルク体を得るためには焼結法が有效であると考えられるが, 大気への暴露によるシリコンの酸化被膜がシリコンスラッジ の焼結を妨げることが予想される ${ }^{6)}$. そこで, 高純度化され 
たシリコンバルク体の作製方法として放電プラズマ焼結 (SPS) 法に注目した．SPS 法は短時間，省エネルギー，低コス 卜で緻密な焼結体を作製できるという特徵を有し ${ }^{7,8}$, さらに 焼結中に還元反応が起こることが期待されている, SPS法を用いた窒化シリコンや炭化シリコン焼結体に関する 報告はあるものの ${ }^{11,12)}$ ，シリコン単体の焼結に関する事例は 少ないようである. そこで本研究では, シリコンウェハのス ライス工程直後の排水から採取した凝集剤の添加されていな いシリコンスラッジをSPS 法により焼結し, 高純度のシリコ ンバルク体の作製を試みた。

\section{2 実験方法}

本研究で用いたシリコンスラッジはシリコンインゴットの スライス工程直後の排水から採取した. 排水は二種類あり, ひとつは $\mathrm{p}$ 型のみ，もう一方はn型と型両方のシリコンイン ゴットをスライスした加工機からの排水である. 以下, これら の排水から採取したスラッジをそれぞれ $\mathrm{p}$ 型スラッジおよび $\mathrm{p}+\mathrm{n}$ 型スラッジと呼ぶ。採取したシリコン研削スラッジは多 量の水分を含んでいるため, 焼結前にホットプレートを用い て $523 \mathrm{~K}$ の加熱温度で脱水処理を施した. 乾燥された粉末を グラファイト製の型にカーボンシートを介して充填し，SPS 装置(SPSシンテックス, SPS-520)を用いて焼結した。装填し たスラッジの量は $5 \mathrm{~g}$ とした．また，焼結温度を 1173,1273 , $1373,1473 \mathrm{~K}$, 保持時間を $600,1800 \mathrm{~s}$ とし, 加圧力は $35 \mathrm{MPa}$ と固定した。得られた焼結体に対し，表面に付着したカーボ ンシートを研磨により削り取り, 微小硬度計 (SHIMADZU, M-86076)を用いてビッカース硬さ試験を行い, 固体密度測定 装置(メトラー・トレド, AT201)を用いてアルキメデス法に より密度を求め, さらにシリコンウェハの密度を求めてそれ に対する相対密度を算出した．また，清净な測定面を得るた めに $10 \%$ フッ化水素水中で1分間浸して自然酸化膜を除去し た焼結体に対し，蛍光X線分析装置 (ZSX100e, RIGAKU)によ る組成分析を行った.さらに, X線回折(XRD)装置(SIMADZU,
XRD-6100)を用いて焼結体の結晶構造を調査した.

\section{3 実験結果および考察}

SPS 法を用いてシリコンスラッジの焼結を行った結果, 全 ての条件においてバルク体が得られた。 $\mathrm{p}$ 型スラッジから得 られた焼結体の外観写真をFig.1に示す.これらは円柱形状に 焼結された試料の上面から撮影した写真である. 1173 おび $1273 \mathrm{~K}$ の温度で焼結した試料は, 保持時間にかかわらず赤み. を帯びた褐色を示した. $1373 \mathrm{~K}$ と焼結温度を高くした試料に おいては, 赤みがやや薄くなった褐色を示した. さらに $1473 \mathrm{~K}$ で焼結した試料においては, 高純度のシリコンバルク体と同 じ暗灭色を呈し，金属様の光沢も示した. $\mathrm{p}+\mathrm{n}$ 型スラッジか ら得られた焼結体の外観についても同様な傾向が見られた。 S. Izumi らは, 分子動力学法によってシリコンの固相成長速

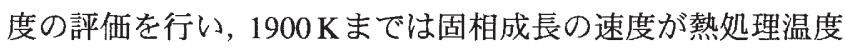
にともない高くなることを示し，さらに不純物のドープに よっても成長速度が高くなることを示した ${ }^{13}$. .したがって, 焼結温度の增加にともない, スラッジ中のシリコン結晶粒子 が成長し, 高純度シリコンの外観に近づいたと推測できる。 以上のことから, SPS 法を用いてシリコンスラッジを焼結す ることでバルク体を得られることが判明した.

次に, 焼結条件と焼結体の密度の関係を調查するために, アルキメデス法により試料およびシリコンウェハの密度を測 定し, シリコンウェハの密度に対する試料の相対密度を算出 した. $\mathrm{p}$ 型および $\mathrm{p}+\mathrm{n}$ 型スラッジを用いた焼結体から得られ た結果をそれぞれFig.2(a)および(b)に示す. Fig.2 (a)より，p型 スラッジから得られた焼結体の相対密度は, 焼結温度にとも ない高くなることが明らかである. 焼結温度 $1173 \mathrm{~K} て ゙$ 作製し た焼結体においては，保持時間の違いによる大きな違いは見 られない. しかし, 焼結温度 $1273 \mathrm{~K}$ 以上での焼結体では, 保 持時間を $600 \mathrm{~s}$ とした試料よりも $1800 \mathrm{~s}$ と長くした試料の方が 相対密度が高くなっていることがわかる. 焼結温度が $1473 \mathrm{~K}$ および保持時間が $1800 \mathrm{~s}$ のときに最大相対密度 $95.7 \%$ を示し

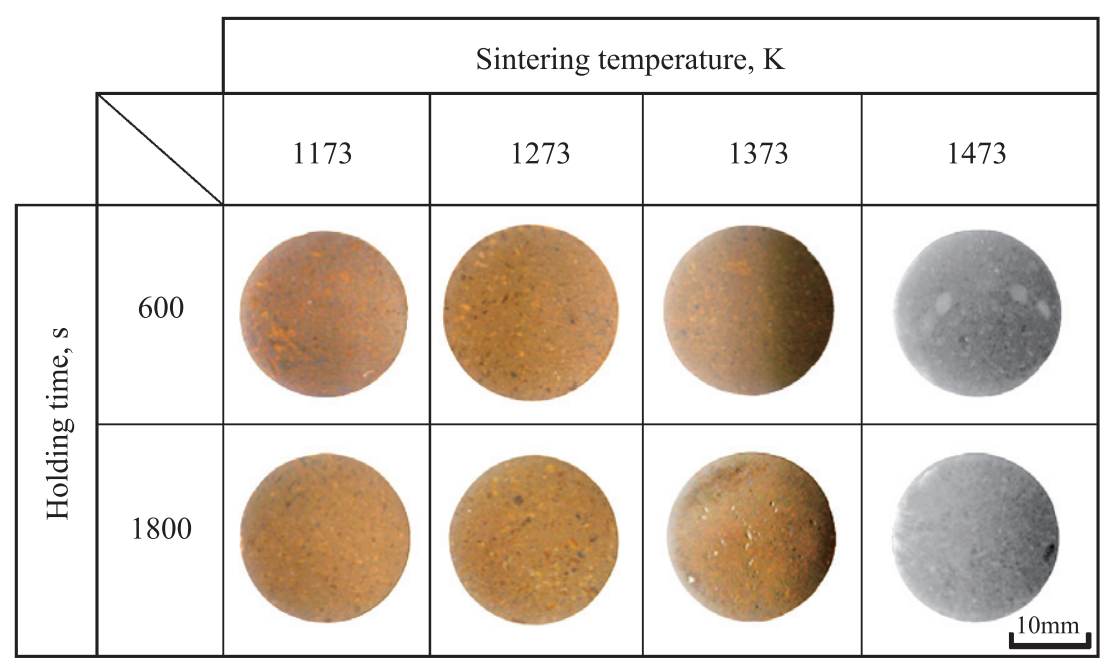

Fig.1 Appearance photographs of Si sintered compacts produced from the p-type sludge. 

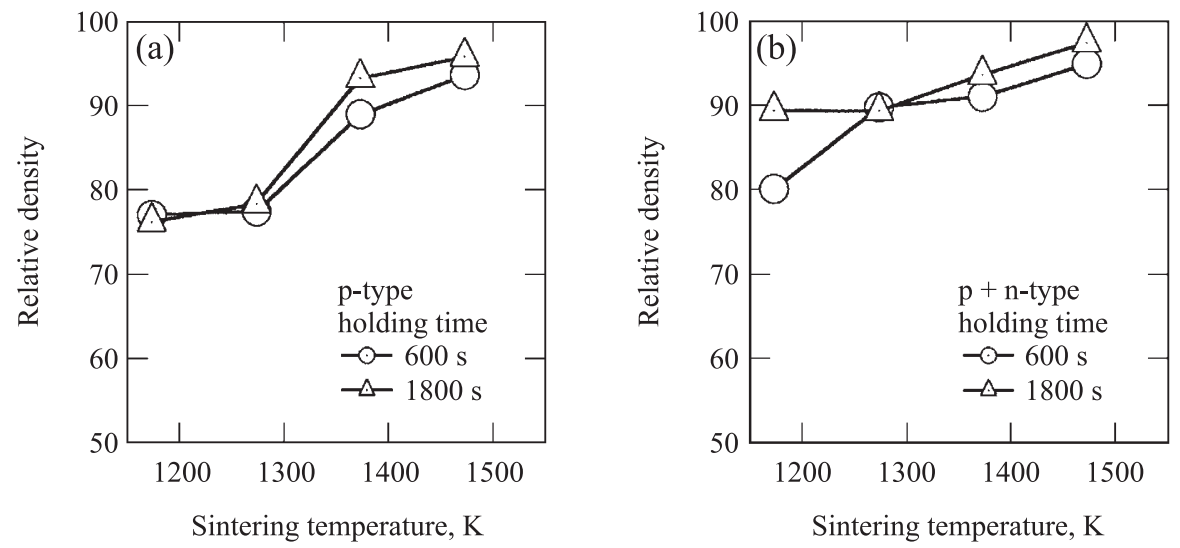

Fig.2 Variations of relative density as a function of sintering temperature for sintered compacts produced from (a) p-type sludge and (b) $\mathrm{p}+\mathrm{n}$-type sludge.
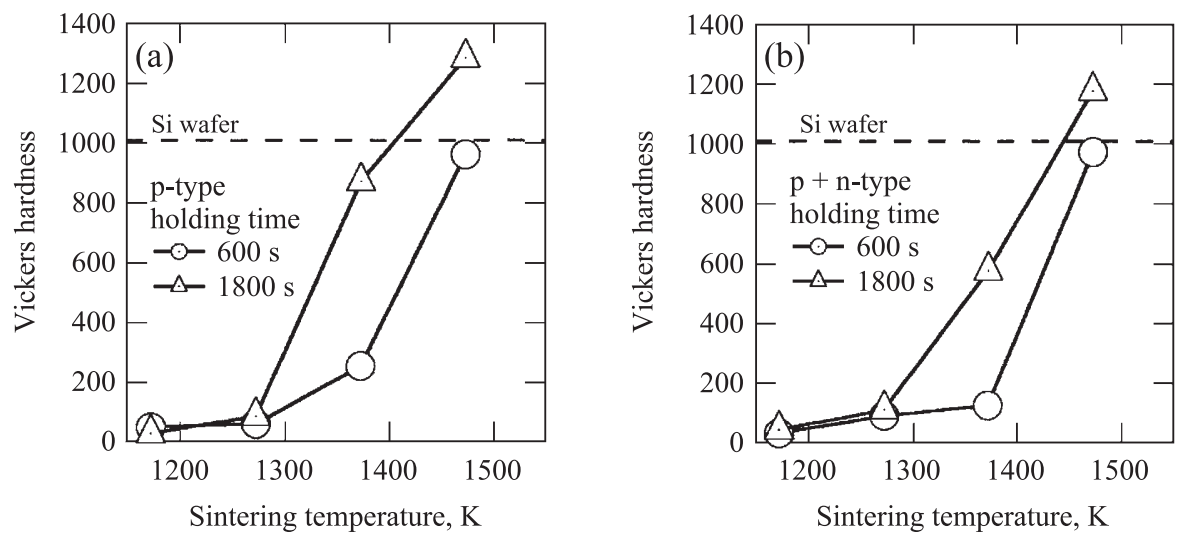

Fig.3 Variations of Vickers hardness as a function of sintering temperature for sintered compacts produced from (a) p-type sludge and (b) $\mathrm{p}+\mathrm{n}$-type sludge.

た. Fig.2 (b) より, p+n 型スラッジから得られた焼結体につ いても，1173 K において大きく異なる相対密度を示すもの の, 概してp 型の場合と同様な相対密度の変化が見出せる.最 大相対密度は $97.5 \%$ であり, その時の焼結条件は $\mathrm{p}$ 型スラッ ジの場合と同じである. 焼結温度および保持時間の上昇に伴 う焼結体の緻密化は, アルミナやアルミニウム合金, 炭化夕 ングステンなどの焼結においても観察される ${ }^{14-16)}$. これらの 緻密化はSPSS法にお污る粉末構成原子の粒界拡散・表面拡散・ 体積拡散が, 焼結温度および保持時間にともない助長される ために進行すると考えられている.したがって, シリコンス ラッジ焼結体の緻密化も同様な現象によるものと推測される. 以上のことから, シリコンスラッジから得られた焼結体の相 対密度は, 本実験の範囲ではより高い焼結温度およびより長 い保持時間とすることにより，高い值を示すことが明らかと なった。

さらに，焼結した試料のビッカース硬さについて述べる. $\mathrm{p}$ 型および $\mathrm{p}+\mathrm{n}$ 型スラッジから得られた焼結体のビッカース 硬さ測定の結果をそれぞれ Fig.3 (a) および (b) に示す. なお， 図中の破線は Si $(100)$ ウエハから得られたビッカース硬さを 示す. Fig.3 (a) より，試料のビッカース硬さは焼結温度にと
もない増加し, 焼結温度が $1473 \mathrm{~K}$ と高くなるとシリコンウェ 八の值に近づくあるいは超過することがわかった. 異なる保 持時間で作製した試料の硬さを同一焼結温度で比較すると, $1173 \mathrm{~K}$ の焼結温度では同等の硬さを示すが, $1273 \mathrm{~K}$ 以上の焼 結温度では保持時間 $600 \mathrm{~s}$ で作製した試料よりも $1800 \mathrm{~s}$ で作製 した試料の方が高い硬さを示した. Fig.3(b) より, p+n 型ス ラッジから得られた焼結体の硬さも， $\mathrm{p}$ 型スラッジのそれと 同様の変化を示す.したがって, 焼結体の硬さは焼結温度お よび保持時間にともなって増加することが明らかとなった. また, これらの硬さの変化は, Fig.2に示した相対密度の変化 と同様な傾向を示す。それ故，シリコン焼結体の硬さ㹥密度 に依存し, 高密度になるに従い硬さが増加すると考えられる。

Fig.3 (a) および(b)において, 焼結温度を $1473 \mathrm{~K}$, 保持時間 を $1800 \mathrm{~s}$ として焼結した試料のビッカース硬さが，シリコン ウェハのそれよりも高い值を示したが, この時の相対密度は シリコンウェハに対して約 $96 \%$ と低い.この矛盾について考 察する. 後述するが, $1473 \mathrm{~K}$ の焼結温度, $1800 \mathrm{~s}$ の保持時間 で焼結した試料中には $24-36$ mass\%の酸素が含まれる.この ときのシリコンに対する酸素の原子数の比は約 $0.56-1.1$ であ る. しかし, Fig.1に示したようにこの焼結体が金属様の光沢 
や暗灰色を示すことから, 含有酸素全てがシリコン原子と結 合しているとは考えにくい．また，試料の表面に水滴を滴下 したときに, 酸化ケイ素では見られない高純度シリコン特有 の撥水効果も確認している. そこで，焼結体中の酸素の形態 に着目する. T. Naruse等の報告によると, SPS 法で作製した アルミナにおいて, 焼結によって酸素原子がアルミニウム原 子から脱離し固体中を移動することが示唆されている ${ }^{10)}$.ま た, Dinesh C. Guptaの著書によると, CZシリコンウェハ中の 格子間酸素の含有量が増加すると, ウエハの硬さが増加する ことが報告されている ${ }^{17)}$ 。ここで，格子間酸素含有量が 2 倍 になると, ウェハの硬さは最大で約 1.5 倍にも増加する。こ れらのことから, 得られた焼結体が示したシリコンウェハよ り高い硬さは,シリコンスラッジに含まれていた酸素原子が, シリコン原子ネットワークの格子間に移動したことに起因す ると言えそうである.

シリコンスラッジおよびシリコン焼結体の組成を比較する ために，蛍光X線装置による組成分析を行った. Fig.4 (a) お よび(b)に，それぞれ保持時間を 600 および $1800 \mathrm{~s}$ として $\mathrm{p}$ 型 シリコンスラッジから作製した焼結体の組成分析結果を示す.
ここで，横軸に sludge と表記された場合の值は，脱水したシ リコンスラッジ粉末の含有元素濃度を示す. 分析の結果から, シリコン焼結体にはシリコンの他に炭素および酸素が含まれ ていることがわかる. また，使用粉末のシリコン濃度が 56.8 mass\%であるのに対し, 焼結によって酸素濃度が減少した結 果, 焼結体のシリコン濃度が 10 mass\%程度上昇して平均で約 64 mass\%となることがわかった. 炭素に関しては, スラッジ における含有量が約 1 mass\% であるのに対し，焼結すること によって平均して約 2 mass\% まで増加するが，これは酸素含 有量が減少したために相対的に微増したものと推測する.焼 結温度を $1473 \mathrm{~K}$ ，保持時間を $1800 \mathrm{~s}$ として作製した焼結体が 最も高い 73.6 mass\%のシリコン濃度を示した．同様に, $\mathrm{p}+\mathrm{n}$ 型スラッジから得られた組成分析結果をFig.5 (a)および(b)に 示す. $\mathrm{p}+\mathrm{n}$ 型スラッジの場合では, 使用粉末のシリコン濃度 が 61.6 mass\%に対して，焼結することで 20 mass\% 程度上昇 し約 85 mass\%になることがわかる. 炭素含有量については, $\mathrm{p}$ 型の場合と同程度の増加を示した. $\mathrm{p}+\mathrm{n}$ 型の焼結体では, 焼 結条件 $1173 \mathrm{~K}$ ，保持時間 $1800 \mathrm{~s}$ において 85.6 mass\% と最も高 い値を示した。酸素含有量の減少は，SPS 法を用いたアルミ
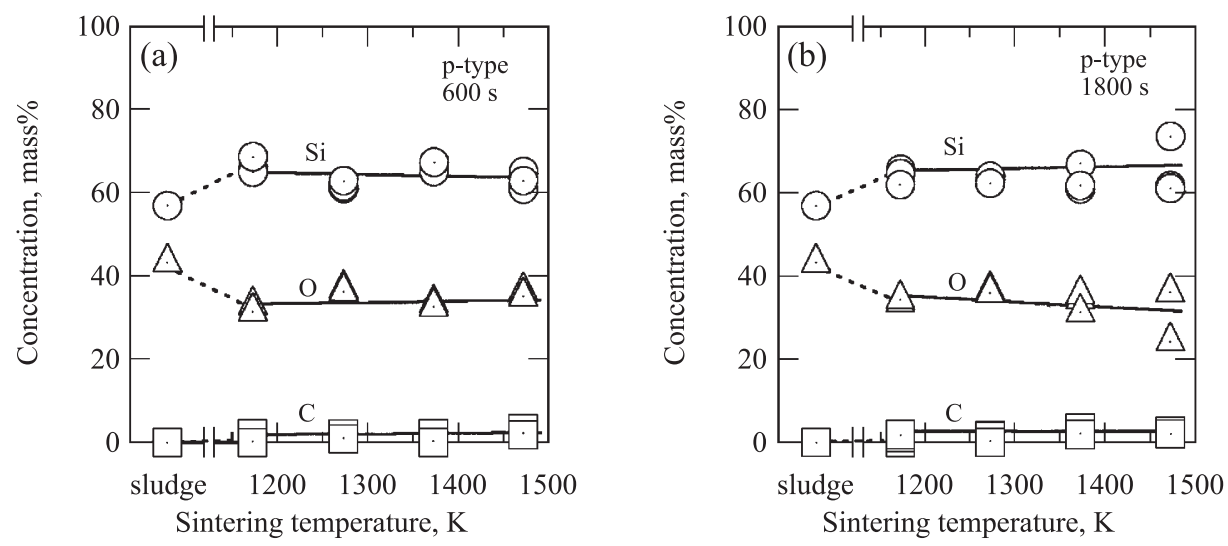

Fig.4 Sintering temperature dependences of contents of silicon, oxygen and carbon in the sintered compacts produced from p-type silicon sludge at the different holding times; (a) $600 \mathrm{~s}$; (b) $1800 \mathrm{~s}$. For comparison, the contents in the p-type sludge are indicated at "sludge" showed in the horizontal axis.
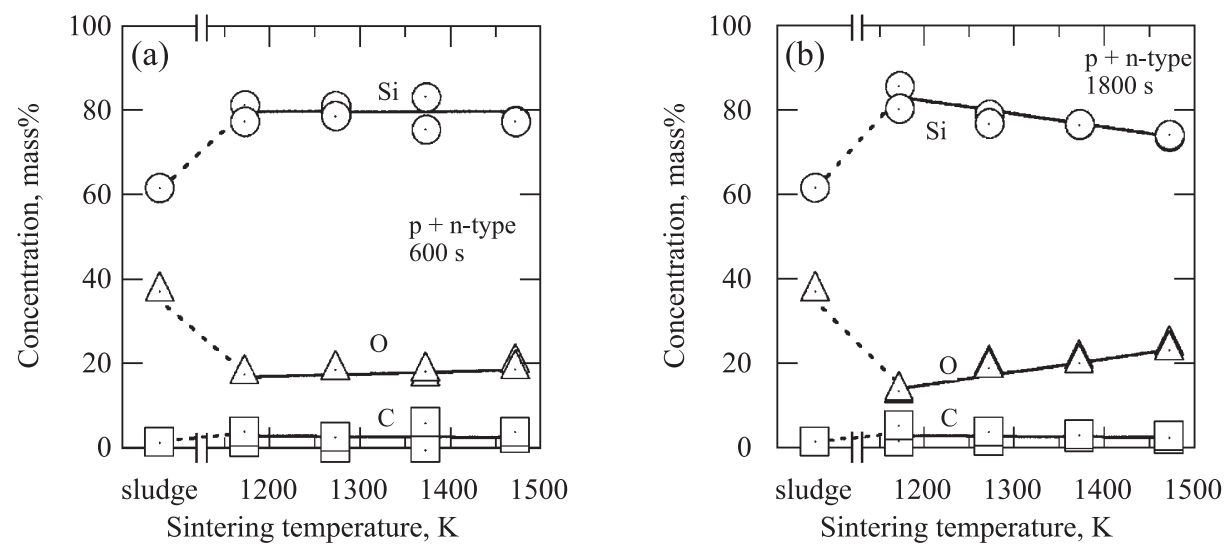

Fig.5 Sintering temperature dependences of contents of silicon, oxygen and carbon in the sintered compacts produced from $\mathrm{p}+\mathrm{n}-\mathrm{type}$ silicon sludge at the different holding times; (a) $600 \mathrm{~s}$; (b) $1800 \mathrm{~s}$. For comparison, the contents in the $\mathrm{p}+\mathrm{n}$-type sludge are indicated at "sludge" showed in the horizontal axis. 
ナ焼結の粉末粒界分析によって示唆された粒界をパスサイト とする酸素原子の移動および気孔での放出が原因と推測され る ${ }^{10)}$. 以上のことから，SPS 法を用いてシリコンスラッジを 用いることにより, スラッジよりも高純度化されたシリコン 焼結体を得られることが明らかとなり，また，焼結すること により酸素濃度が低下することから, 焼結中に還元反応が起 きることが示唆された。

Fig.4より, p 型スラッジを用いた焼結体の酸素濃度が焼結 温度の上昇にともない減少傾向を示すのに対し, Fig.5に示す ように $\mathrm{p}+\mathrm{n}$ 型スラッジを用いた焼結体の場合は，焼結温度 $1173 \mathrm{~K}$ で最も低い酸素濃度を示し, 焼結温度にともない酸素 濃度が増加することが見出せる．この増加は，シリコンの結 晶化にともない真空容器中の残留ガス起因の酸素が結晶粒界 に拡散したためと推測されるが, 原料としたスラッジの違い によるこれらの酸素含有量の挙動の差異は, 酸素原子の拡散 が粒界をパスサイトとするのであれば, 材料であるスラッジ の結晶粒径や粉末の粒子サイズに依存する可能性がある.

SPS法を用いたシリコンスラッジの焼結によって得られた 試料の結晶性を XRD 分析により評価した。 p 型シリコンス ラッジおよびそれを用いて保持時間を $1800 \mathrm{~s}$ とて焼結した 試料のXRDパターンを Fig.6 (a)に示す。ここで, 図中の温度 は焼結温度を示す.スラッジおよび各焼結体のXRDパターン において，いずれも28.4,47.3および56.1ににそれぞれシリコ ンの (100), (220) および(311) 回折ピークが観察される. した がって, SPS 法を用いた焼結によって多結晶シリコンのバル ク体を得られたことが明らかになった。また，すべてのXRD パターンにおいて， $22^{\circ}$ 付近(図中の○印)にアモルファス状 の二酸化ケイ素に起因する強度の低いブロードなピークが観

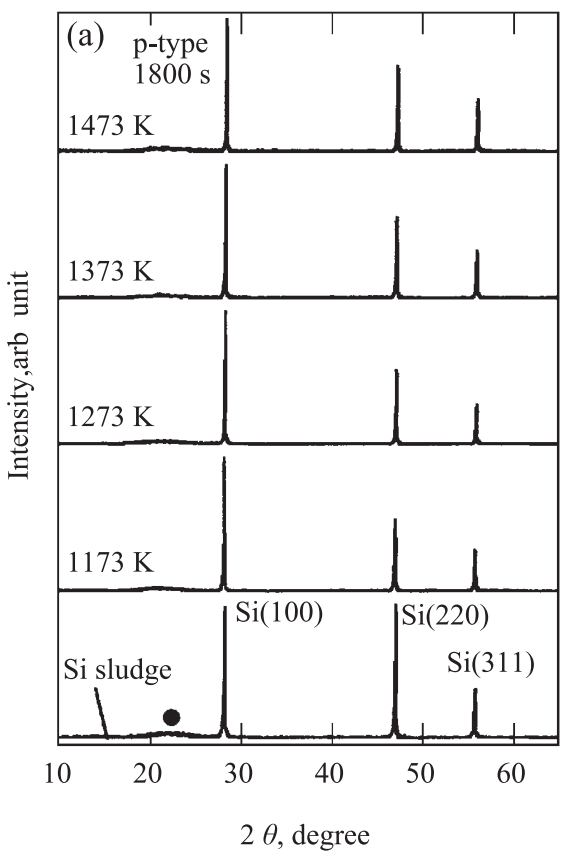

察される ${ }^{18)}$.このことから，スラッジおよび焼結体中に含ま れる酸素はアモルファス構造の二酸化ケイ素の形態でも存在 することが判明した. また, $\mathrm{Si}-\mathrm{C}$ 化合物に関連する回折ピー クは観察されなかった。これは, 組成分析の結果からCの含 有量がわずかであったためと考えられる.

Fig.6(b)に示した $22^{\circ}$ 付近を拡大したXRDパターンにおい て,シリコンスラッジにおける二酸化ケイ素起因のブロード なピークが，焼結体におけるそれよりも明膫に観察される. そこで, 各試料におけるこのピークの強度を求め, Si(100)回 折ピークの強度に対する強度比 $I_{\mathrm{glass}} / I_{\mathrm{Si}(100)}$ を求めた. 焼結温度 に対する強度比 $I_{\mathrm{glass}} / I_{\mathrm{Si}(100)}$ の変化を Fig.7に示す。ここで, 横 軸に sludge と表記された場合の值は, シリコンスラッジ粉末

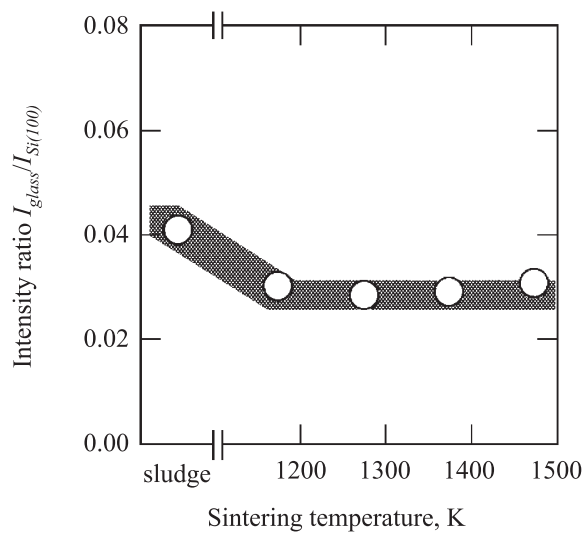

Fig.7 Variation of intensity ratio $I_{\text {glass }} / I_{\mathrm{Si}(100)}$ of sintered compacts produced from the p-type silicon sludge as a function of the sintering temperature. For comparison, the ratio of $\mathrm{p}$ type sludge is indicated at "sludge" showed in the horizontal axis.

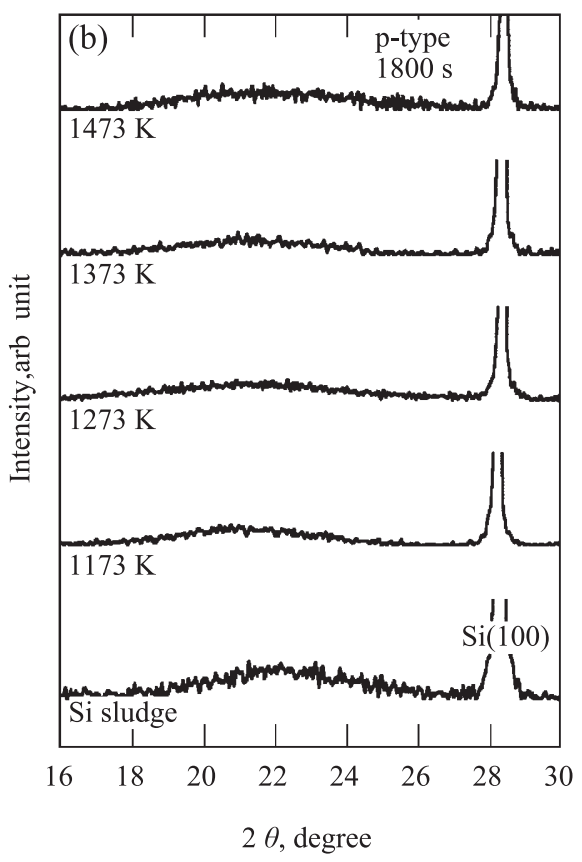

Fig.6 (a) XRD patterns of p-type silicon sludge and the sintered compacts produced at the indicated temperature from the sludge, and (b) enlarged view around broad peak at 22 degree in (a). 
の強度比である. Fig.7より, スラッジの強度比が約 $0.04 に$ 対 し，焼結体のそれが約 0.03 と低い值を示すことが分かる.し たがって, XRD分析結果からも定性的に酸素濃度の減少が確 認でき, SPS 法を用いてシリコンスラッジを焼結する際にも 還元反応が起こることが示唆された.

\section{4 結 言}

SPS法を用いることによりシリコン研削スラッジからシリ コンバルク体を作製できることが明らかになった. 焼結体の ビッカース硬さは保持時間および焼結温度にともない上昇し た. 焼結体の密度もまた焼結温度および保持時間にともない 増加した. SPS 法でシリコン研削スラッジを $1173 \mathrm{~K}$ 以上の温 度で焼結することにより，61.6 mass\%から 85.6 mass\%まで高 純度化されたシリコンバルク体を得られることが判明した。 本研究の一部は特許出願中である (特願 2009-005569).

\section{文献}

1) M. Akasaka, T. Iida, et al.: "Fabrication of $\mathrm{Mg}_{2} \mathrm{Si}$ from a Reused-silicon Source and its Thermoelectric Characteristics", Mater. Res. Soc. Symp. Proc., 1044(2008)U6.15.1- U6.15.6.

2) E. Williams: "Global Production Chains and Sustainability -The case of high-purity silicon and its applications in IT and renewable energy-", United Nations University/Institute of Advanced Studies, (2000)77-78.

3) "Profile of the Electronics and Computer Industry", US Environmental Protection Agency document, No. EPA/310-R95-002 (1995)62-63.

4) L. Martinelli and W. Worth: "Global Warming: A White Paper on the Science, Policies and Control Technologies that Impact the U.S. Semiconductor Industry", SEMATECH Technology Transfer paper, (1994) No. 9311207

5) H. Nakato and M. Nitta: "Reuse Technology of High Purity Silicon Sludge", J. Jpn. Soc. Precis. Eng., 72(2006)573-577.

6) T. Nagae, M. Yokota, et al.: "Effects of Pulse Current on an Aluminum Powder Oxide Layer During Pulse Current Pressure Sintering", Mater. Trans., 43(2002)1390-1397.
7) G.-D. Zhan, J. Kuntz, et al.: "A Novel Processing Route to Develop a Dense Nanocrystalline Alumina Matrix $(<100 \mathrm{~nm})$ Nanocomposite Material", J. Am. Ceram. Soc., 86(2003)200202.

8) S.H. Risbud, C-H. Shan, et al.: "Retention of nanostructure in aluminum oxide by very rapid sintering at $1150^{\circ} \mathrm{C}$ ", J. Mater. Res., 10(1995)237-239.

9) H. Maiwa: "Preparation and Properties of $\mathrm{BaTiO}_{3}$ Ceramics by Spark Plasma Sintering", Jpn. J. Appl. Phys., 47(2008)76467649.

10) Y. Makino, ed.: "Review of Pulsed Electric Field Processing", Kansai Pulsed Electric Current Forum, (2009)122-129.

11) T. Nishimura, M. Mitomo, et al.: "Fabrication of silicon nitride nano-ceramics by spark plasma sintering", J. Mater. Sci. Res. Let., 14(1995) 1046-1047.

12) N. Tamari, T. Tanaka, et al.: "Effect of spark plasma sintering on densification and mechanical-properties of silicon-carbide", J. Ceramic Soc. Jpn., 103(1995)740-742.

13) S. Izumi, K. Murai, et al.: "Influence of Impurity Atoms on the Rate of Solid Phase Epitaxy: Molecular Dynamics Study", Third Multi-scale Materials Modeling (MMM-III) Conf., (2006) 18-22.

14) Y. Makino: "Nano-structured materials synthesized by pulsed high current heating", J. High Temperature Soc., 13(2005) 202208.

15) G. Xie, O. Ohashi, et al.: "Sintering Behavior of Aluminum Powder by Spark Plasma Sintering", Trans. MRS of Japan, 27 (2002)743-746.

16) B. Huang, L.D. Chen, et al.: "Bulk ultrafine binderless WC prepared by spark plasma sintering", Scripta Materialia, 54 (2006) 441-445.

17) D.C. Gupta: "Semiconductor fabrication: technology and metrology", ASTM International, (1989) 45.

18) H. Graetsch, A. Mosset, et al.: "XRD AND ${ }^{29}$ Si MAS-NMR Study on Some Non-Crystalline Silica Minerals", J. Non-Cryst. Solids, 119(1990)173-180. 